\title{
O projeto ético-político da humanização: conceitos, métodos e identidade
}

The ethical and political humanization project: concepts, methods and identity El proyecto ético-político de la humanización: conceptos, métodos e identidad

Debater o texto de Regina Benevides e Eduardo Passos é uma oportunidade ímpar de reflexão. Primeiro pela profundidade de sua argumentação; segundo, pela experiência privilegiada destes autores na proposição e consolidação de uma política de humanização para o País. São autores, portanto, que têm a perfeita dimensão das possibilidades e obstáculos existentes para tal projeto. Então, aceitando frontalmente a imprescindível e inquietante proposta de Regina e Eduardo, buscarei refletir, a partir de suas colocações, os desafios conceituais e metodológicos postos no projeto éticopolítico da humanização da produção de cuidados em saúde.

O primeiro passo seria argumentar sobre o conceito e seu contexto de reconhecimento; o conceito e suas diferentes formas de institucionalização, seja na letra da Política, seja no campo das "práticas instituintes-instituídas", tecendo, aí, alguns de seus desafios metodológicos.

Como lembram Regina e Eduardo, a plasticidade e polissemia do conceito de humanização já foram amplamente debatidas (Casate, 2005; Deslandes, 2004; Puccini \& Cecílio, 2004). Suas possibilidades interpretativas variam desde o senso comum do "ser bom com o outro que sofre", num mix de altruísmo caritativo e humanismo naif, passando por leituras essencialistas da busca do que seria o fundante do Humano, até as leituras de um humanismo revisitado, aberto sinergicamente ao singular de cada experiência humana em suas necessidades e ao mesmo tempo ancorado numa ética da vida, portanto universal (Benevides \& Passos, 2005).

Anexo ainda a proposição de um modelo de produção de cuidados mais resolutivo, centrado em comunicação que articula a troca de informações e saberes, diálogo, escuta de expectativas/demandas e a partilha de decisões entre profissionais, gestores e usuários (Benevides \& Passos, 2005; Deslandes, 2004; 2005). Pensar a comunicação traz implícita a tarefa de discutir politicamente os diferentes capitais e agentes envolvidos nesta proposta e os meios de comunicabilidade (comunhão e negociação de sentidos e interpretações).

\footnotetext{
${ }^{1}$ Pesquisadora, Fundação Oswaldo Cruz/Instituto Fernandes Figueira, Rio de Janeiro, RJ. <desland@iff.fiocruz.br>
} 


\section{DEBATES}

Muito apropriadamente Regina e Eduardo alertam quanto ao contexto real no qual se inserem as (im)possibilidades desta proposta: um modelo de assistência secularmente hierarquizado, fragmentado e calcado numa lógica técnico-burocrática.

Vemos ainda que o conceito de humanização se alinha a uma série de propostas de revisão e de mudança das relações entre equipes, profissionais, gestores e usuários dos serviços. A aposta nas "tecnologias relacionais" é clara. Fala-se do emprego das tecnologias de escuta, acolhimento, diálogo e negociação para a produção e gestão do cuidado.

A Política Nacional de Humanização (PNH) (Brasil, 2004), por sua vez, não demarca um conceito, habilmente afirma apenas um "entendimento" do seu coletivo de formuladores:

Assim, entendemos Humanização como: valorização dos diferentes sujeitos implicados no processo de produção de saúde: usuários, trabalhadores e gestores; fomento da autonomia e do protagonismo desses sujeitos; aumento do grau de co-responsabilidade na produção de saúde e de sujeitos; estabelecimento de vínculos solidários e de participação coletiva no processo de gestão; identificação das necessidades de saúde; mudança nos modelos de atenção e gestão dos processos de trabalho tendo como foco as necessidades dos cidadãos e a produção de saúde; compromisso com a ambiência, melhoria das condições de trabalho e de atendimento. (Brasil, 2004)

Esta opção semiótica e política evita o fechamento de uma definição programática, é certo. Por outro lado, não possibilita a vinculação com uma "imagem-objetivo" clara, além de permitir a identificação destas assertivas com vários princípios e orientações já disseminados pelo modelo de políticas e práticas de saúde que o SUS busca construir (valorização dos sujeitos, processos de gestão participativa e solidária, protagonismo dos sujeitos, ações de saúde centradas nas necessidades reais de saúde das populações e dos indivíduos, democratização das relações). A primeira vista, parece faltar nesta definição uma identidade do que busca designar.

A leitura do documento permite perceber que, de fato, os itens desta proposição reaparecem como alguns dos princípios da mesma Política. Se a definição do conceito ganha a forma de uma proposição "principialista" o que isso pode nos indicar? Aventuro como especulação que o desejo da transversalidade que a política almeja então se amplia, dado que este conceito-princípio pode estar presente em vários níveis da produção de cuidados de saúde, da recepção do usuário à gestão e planejamento das ações. Contudo, um elemento isolado desta proposição (valorização dos sujeitos, fomento de autonomia e protagonismo etc) não parece garantir a identidade de um projeto de humanização, pois sua aplicação estaria aberta a inúmeras possibilidades de leituras formalizantes e burocratizadas.

Regina e Eduardo assumem este dilema: uma política não pode ser genérica a ponto de se confundir com os próprios princípios do SUS, nem cair na especificidade de uma definição ortopedicamente reguladora. Apontam um elemento diferencial do que poderia ser um eixo identitário da proposta de humanização: processos de subjetivação transformadores, isto é, envolvendo sujeitos coletivos que nas práticas concretas e cotidianas transformam o modo de produzir cuidados de saúde, transformando-se a si também. Daí a estratégica posição que a proposta de humanização passa a desfrutar ao ter o estatuto de uma Política. Aglutina um poder mobilizador de debate e de ações que não haveria se fosse vista como mais uma diretriz das ações de saúde. 
Ao pensar nesses processos de subjetivação voltamos ao jogo das interações, das relações face-a-face que constróem o cotidiano do que costumamos chamar de "assistência". Mas, como sabemos, este projeto somente se realiza se for tomado como um modo de gestão, um modo de realizar a atenção em saúde, uma praxis. Carece, portanto, de estratégias não só de produção, mas de reprodução deste modelo. Neste sentido, o investimento na formação de profissionais e gestores é estratégia importante, cuja sustentabilidade se dá a partir da disseminação de mecanismos ideológicos contrahegemônicos e de alianças que garantam adesão e continuidade de tal projeto.

Cabe ainda indagar, qual modelo se deseja? Certamente esta resposta só é possível a partir de múltiplas vozes e expressões. A PNH (Brasil, 2004) defende como "marcas" a serem atingidas um atendimento resolutivo e acolhedor, combatendo a despersonalização a que são submetidos os usuários dos serviços, garantindo-lhes seus direitos instituídos em "códigos dos usuários", além de garantir educação permanente aos profissionais bem como a participação nos modos de gestão.

Sem entrar na argumentação destas marcas propostas, que por si só dariam longa reflexão, penso que dois desafios se apresentam à construção deste modelo e, conseqüentemente, aos seus agentes: a produção de um cuidado orientado pelo reconhecimento de pessoa (o sentido de ser membro, de pertencimento a um ethos, a uma cultura, a um grupo que define os próprios significados do "eu") e de sujeito (o sentido de uma identidade a partir de uma biografia singular, articulada a uma cultura, capaz de dotar de legitimidade a autonomia de cada um). Resgato aí a crucialidade da politização do estatuto de pessoa e de sujeito. A definição de pessoa passa pelo reconhecimento e respeito a outros e distintos referenciais culturais. A noção de sujeito nos lança ao discurso ético da autonomia, das escolhas e decisões à luz das condições de gênero, posição social e etnia/raça. É sempre oportuno perguntar quem goza do status de pessoa e de sujeito nas práticas de assistência prestada nos serviços de saúde? Quais capitais de protagonismo e autonomia os diferentes atores usufruem? Quais as margens e mecanismos de negociação e ampliação destas fronteiras? Penso que buscar enfrentar estas questões é, como bem pontuam Regina e Eduardo, criar as bases de um movimento realmente instituinte do projeto de humanização em contexto ao ideário do SUS.

\section{Referências:}

BENEVIDES, R.; PASSOS, E. A humanização como dimensão pública das políticas de saúde. Ciênc. Saúde Colet., v.10, n.3, 2005. (no prelo).

BRASIL. Ministério da Saúde. 2004. Política Nacional de Humanização. Disponível em: <http:// portal.saude.gov.br/saude/area.cfm?id_area=390>. Acesso em: 5 fev. 2005.

CASATE, J. C.; CORRÊA, A. K. Humanização do atendimento em saúde: conhecimento veiculado na literatura brasileira de enfermagem. Rev. Lat-Am. Enfermag., v.13, n.1, p.105-11, 2005.

DESLANDES, S. F. Análise do discurso oficial sobre humanização da assistência hospitalar. Ciênc. Saúde Colet., v.9, n.1, p.7-13, 2004.

DESLANDES, S. F. A ótica de gestores sobre a humanização da assistência nas maternidades municipais do Rio de Janeiro. Ciênc. Saúde Colet., v.10, n.3, 2005. (no prelo).

PUCCINI, P. T.; CECÍLIO, L. C. O. A humanização dos serviços e o direito à saúde. Cad. Saúde Pública, v.20, n.5, p.1342-53, 2004. 